A UNITEO STATES OEPARTMENT OF COMMERCE

PUBLICATION

U.S. DEPARTMENT OF COMMERCE

National Oceanic and Atmospheric Administration

National Marine Fisheries Service
Sanitation Guidelines for the Control of Salmonella in the Production of Fish Meal 


\section{NOAA TECHNICAL REPORTS}

\section{National Marine Fisheries Service, Circulars}

The major responsibilities of the National Marine Fisheries Service (NMFS) are to monitor and assess the abundance and geographic distribution of fishery resources, to understand and predict fluctuations in the quantity and distribution of these resources, and to establish levels for optimum use of the resources. NMFS is also charged with the development and implementation of policies for managing national fishing grounds, development and enforcement of domestic fisheries regulations, surveillance of foreign fishing off United States coastal waters, and the development and enforcement of international fishery agreements and policies. NMFS also assists the fishing industry through marketing service and economic analysis programs, and mortgage insurance and vessel construction subsidies. It collects, analyses, and publishes statistics on various phases of the industry.

The NOAA Technical Report NMFS CIRC series continues a series that has been in existence since 1941. The Circulars are technical publications of general interest intended to aid conservation and management. Publications that review in considerable detail and at a high technical level certain broad areas of research appear in this series. Technical papers originating in economics studies and from management investigations appear in the Circular series.

NOAA Technical Reports NMFS CIRC are available free in limited numbers to governmental agencies, both Federal and State. They are also available in exchange for other scientific and technical publications in the marine sciences. Individual copies may be obtained (unless otherwise noted) from NOAA Publications Section, Rockville, Md. 20852. Recent Circulars are:

315. Synopsis of biological data on the chum salmon, Oncorhynchus keta (Walbaum) 1792. By Richard G. Bakkala. March 1970. iii +89 pp., 15 figs., 51 tables.

319. Bureau of Commercial Fisheries Great Lakes Fishery Laboratory, Ann Arbor, Michigan. By Bureau of Commercial Fisheries. March 1970, 8 pp., 7 figs.

330. EASTROPAC Atlas: Vols. 4, 2. Catalog No. I $49.4: 330 /$ (vol.) 11 vols. ( $\$ 4.75$ each). Available from the Superintendent of Documents, Washington, D.C. 20402.

331. Guidelines for the processing of hot-smoked chub. By H. L. Seagran, J. T. Graikoski, and J. A. Emerson. January 1970, iv + 23 pp., 8 figs., 2 tables.

332. Pacific hake. (12 articles by 20 authors.) March 1970, iii + 152 pp., 72 figs., 47 tables.

333. Recommended practices for vessel sanitation and fish handling. By Edgar W. Bowman and Alfred Larsen. March 1970 , iv +27 pp., 6 figs.

335. Progress report of the Bureau of Commercial Fisheries Center for Estuarine and Menhaden Research, Pesticide Field Station, Gulf Breeze, Fla., fiscal year 1969. By the Laboratory staff. August 1970, iii + 33 pp., 29 figs., 12 tables.

336. The northern fur seal. By Ralph C. Baker, Ford Wilke, and C. Howard Baltzo. April 1970, iii + 19 pp., 13 figs.

337. Program of Division of Economic Research, Bureau of Commerecial Fisheries, fiscal year 1969. By Division of Economic Research. April 1970, iii + 29 pp., 12 figs., 7 tables.
338. Bureau of Commercial Fisheries Biological Laboratory, Auke Bay, Alaska. By Bureau of Commercial Fisheries. June 1970, 8 pp., 6 figs.

339. Salmon research at Ice Harbor Dam. By Wesley J. Ebel. April 1970, 6 pp., 4 figs.

340. Bureau of Commercial Fisheries Technological Laboratory, Gloucester, Massachusetts. By Bureau of Commercial Fisheries. June 1970, 8 pp., 8 figs.

341. Report of the Bureau of Commercial Fisheries Biological Laboratory, Beaufort, N.C., for the fiscal year ending June 30, 1968. By the Laboratory staff. August 1970 , iii +24 pp., 11 figs., 16 tables.

342. Report of the Bureau of Commercial Fisheries Biological Laboratory, St. Petersburg Beach, Florida, fiscal year 1969. By the Laboratory staff. August 1970, iii +22 pp., 20 figs., 8 tables.

343. Report of the Bureau of Commercial Fisheries Biological Laboratory, Galveston, Texas, fiscal year 1969. By the Laboratory staff. August 1970, iii +39 pp., 28 figs., 9 tables.

344. Bureau of Commercial Fisheries Tropical Atlantic Biological Laboratory progress in research 1965-69, Miami, Florida. By Ann Weeks. October 1970 , iv +65 pp., 53 figs.

346. Sportsman's guide to handling, smoking, and preserving Great Lakes coho salmon. By Shearon Dudley, J. T. Graikoski, H. L. Seagran, and Paul M. Earl. September 1970, iii +28 pp., 15 figs.

347. Synopsis of biological data on Pacific ocean perch, Sebastodes alutus. By Richard L. Major and Herbert H. Shippen. December 1970, iii +38 pp., 31 figs., 11 tables.

Continued on inside back cover. 


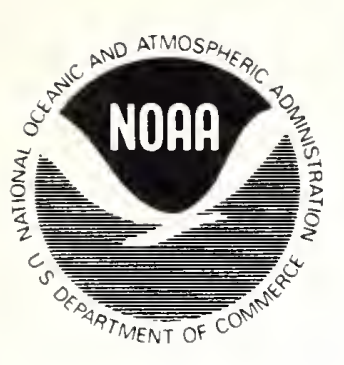

U.S. DEPARTMENT OF COMMERCE Maurice H. Stans, Secretary NATIONAL OCEANIC AND ATMOSPHERIC ADMINISTRATION Robert M. White, Administrator

NATIONAL MARINE FISHERIES SERVICE

Philip M. Roedel, Director

NOAA Technical Report NMFS CIRC-354

Sanitation Guidelines for the Control of
Salmonella in the Production of Fish Meal

E. SPENCER GARRETT and RICHARD HAMILTON

SEATLE, WA.

October 1971 


\section{CONTENTS}

Page

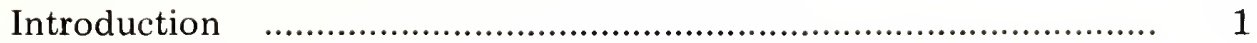

Salmonellosis $\quad$................................................................... 1

How are salmonellae spread? $\quad$................................................ 1

How is the fish reduction industry concerned with salmonellae? (...................................................................... 1

Salmonellae control procedures $\quad$................................................. 2

Plant grounds $\quad$...................................................................... 2

Plant buildings and equipment ............................................ 2

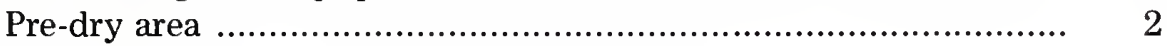

Post-dry area $\quad$.................................................................. 3

Cleaning and disinfecting ...................................................... 4

Containers and transportation ............................................... 4

Sampling and laboratory examination ...................................... 5

Personnel ............................................................................. 5

Management responsibility $\quad$................................................... 6

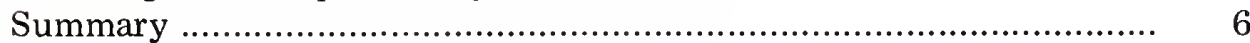

\section{FIGURES}

No. $\quad$ Page

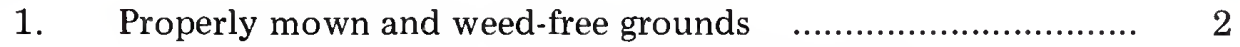

2. Dual type screening: insect screen covered with "rat wire" ..................................................................... 3

3. Properly covered conveyor .......................................... 3

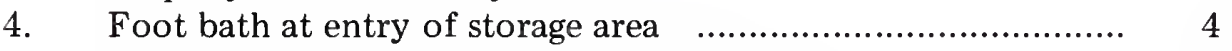

5. Use of vacuum machine aids in dust control ...................... 4

6. One method for proper storage of the finished product ........ $\quad 5$

7. Diagram showing method of sampling bulk which has been loaded upon a vehicle ...................................................... 5

8. Instructional signs remind employees of proper sanitary

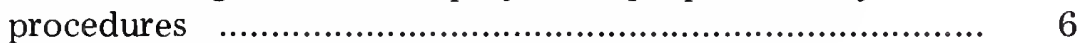

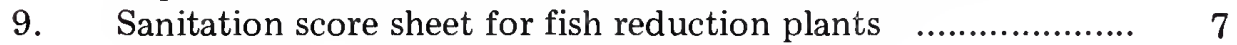


Digitized by the Internet Archive in 2013 


\title{
SANITATION GUIDELINES FOR THE CONTROL OF SALMONELLA IN THE PRODUCTION OF FISH MEAL
}

\author{
By \\ E. Spencer Garrett and Richard Hamilton \\ National Marine Fisheries Service
}

\begin{abstract}
A detailed description of the scope and magnitude of the Salmonella problem as it relates to the manufacture of fish meal is discussed. Specific control steps and procedures are outlined which, if followed, should keep Salmonella contamination to a minimum in fish reduction plants.
\end{abstract}

\section{INTRODUCTION}

\section{Salmonellosis}

Salmonellosis is a disease caused by eating food that is contaminated by bacteria known as Salmonella. There are over 1300 different types of Salmonella. The disease caused by these bacteria is usually characterized by fever, nausea, vomiting, and diarrhea. While there is no way to measure accurately the total cost of salmonellosis to our economy, the cost has been estimated to be at least $\$ 300$ million annually. It has been further estimated that over 2 million individuals are infected with Salmonella annually. When one considers the associated costs of medical care and time loss at this attack rate and adds to this the substantial losses to the livestock and poultry industries, the $\$ 300$ million appears to be a low figure.

\section{How are Salmonellae Spread?}

Salmonella normally inhabit the lower intestine of such animals as rodents and birds. Unpublished reports have indicated that up to $95 \%$ of all rat faeces are positive for Salmonella, and 40 to $60 \%$ of some wild bird species are positive. Carriers, that is, individuals which harbor salmonellae without apparent harm, occur both in human and domestic animal populations and are capable of spreading the infection to susceptible hosts.

Since the only way salmonellosis may be contracted is to ingest food which has either directly or indirectly been contaminated with faeces or urine from a diseased individual, transmission of the organism may be by direct or mechanical means. Methods of direct contamination are obvious. Mechanical transmission is facilitated by insects such as flies, roaches, spiders, weevils, beetles, etc., contaminated implements and clothing, and/or dust.

\section{How is the Fish Reduction Industry Concerned with Salmonellae?}

Scientists both in the United States and abroad have reported the contamination and recontamination of fish meal and scrap with Salmonella. Epidemiologists have suspected the source of Salmonella microorganisms in some cases of human salmonellosis to be from the fish meal portion of poultry feed. Eggs and meat have become indirectly contaminated from feeds, thereby causing outbreaks of salmonellosis when consumed by the unsuspecting public. As a result of such instances the Federal Government has recently banned the interstate shipment of fish meal and other animal feed ingredients contaminated with salmonellae. 


\section{SALMONELLAE CONTROL PROCEDURES}

Research done by National Marine Fisheries Service (formerly Bureau of Commercial Fisheries) scientists has shown that a temperature of $190^{\circ} \mathrm{F}$ held for 10 minutes reduces salmonellae in fish meal to nondetectable levels. It is generally agreed that properly operated dryers being fed properly prepared scrap will permit the material to attain these time-temperature requirements. This being the case, when salmonellae are discovered in properly dried meal, the occurrence is a function of recontamination. This could happen in several ways. The following would be some of the most obvious:

\section{Improper pest control program.}

\section{Improper building and/or equipment} design.

3. Improperly operated equipment.

4. Employee malpractice.

5. Airborne contamination (dust).

All suggested preventive measures listed hereinafter will be aimed toward preventing recontamination by the above ways.

\section{Plant Grounds}

The grounds should be clean, orderly, weedfree, and cut routinely (Fig. 1). For those areas which are inaccessible to a mower, weed control may be implemented by chemical defoliants and other herbicides. Local extension county agents will be more than willing to advise those inexperienced in the use of chemical defoliants in the proper procedures to be followed. Extreme caution must be exercised in the use of those chemical defoliants in order to protect the environment from unwanted pesticide contamination, as well as to prevent erosion. A listing of chemical compounds approved by the U.S. Department of the Interior/U.S. Department of Agriculture is available from the Office of Fish Inspection, National Marine Fisheries Service, Washington, D.C. 20240. When plant grounds are properly

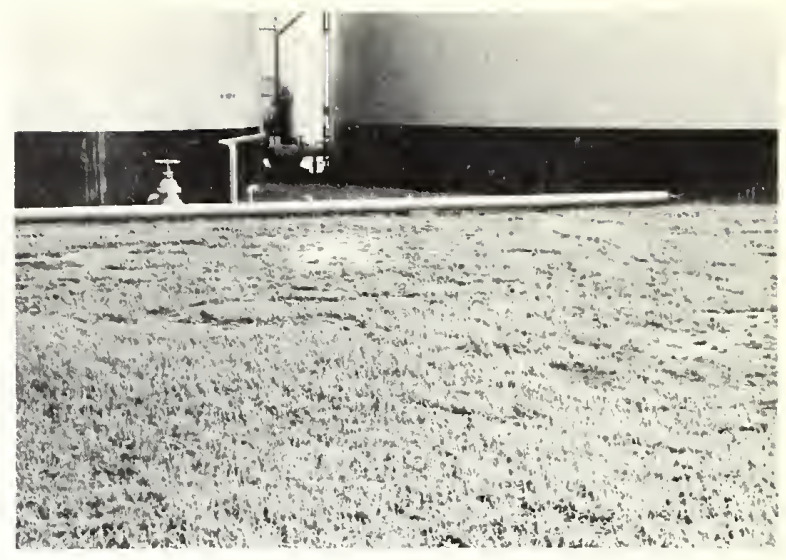

Figure 1. Properly mown and weed-free grounds.

maintained the incidence of ground rodents and insects is lowered. Crawling insects and other pests may also be controlled by the use of pesticides. Any pesticides used, however, should bear approval by the U.S. Department of Agriculture and be used according to the directions on the label.

The entire plant lot should be well drained and free of standing water. Additionally, all trash heaps should be removed and covered waste disposal containers should be provided.

\section{Plant Buildings and Equipment}

Plant buildings should be of sound construction and maintained in good repair. For purposes of a discussion of salmonellae control, any fish meal plant may be divided into two subdivisions, the pre- and post-dry areas. This division is based on the concept that it is possible to destroy Salmonella in the product prior to placing the meal in the storehouse. Once this is done, the next task the processor faces is to prevent recontamination of the meal in the warehouse (post-dry area).

\section{Pre-Dry Area}

All floors in the pre-dry area should be smooth and of a material which may easily be hosed down. Proper drainage is necessary in order to eliminate standing water, which provides a suitable environment for the breeding of flies and multiplication of microorganisms. Water should be removed as quickly as possible after accumulation. Inaccessible puddles of standing water may be eliminated as breeding 
areas by covering them with pine oil until such time as they can be removed.

Raw material, defined as all fish material used in the production of fish meal prior to drying, should be processed as soon after unloading as possible. Cooking temperatures and times should be controlled to assure that the raw material is heated uniformly throughout.

Presses, cookers, and other raw material processing equipment in the pre-dry area should be readily accessible for cleaning, of sufficient design for the load, and as leakproof as possible. Press cake should never be allowed to remain in dryers and/or drags between runs, nor should dead fish be allowed to remain in conveyors or boxes, or on the ground.

Since processing operations usually begin before the temperature of all equipment has stabilized, it is recommended that a return screw conveyor or some other suitable device be installed from the dryer exit back to the cooker. After such installation has been made, all material passed through the dryer for at least the first 45 minutes of operation should be recycled back through the cooker. This should allow for a complete reduction of Salmonella in the press cake to a nondetectable level.

\section{Post-Dry Area}

Once the acceptable product is conveyed to the post-dry area, the next concern is to prevent recontamination of the product with Salmonella. The only way to receive a reasonable degree of assurance that recontamination does not occur is for the post-dry area to be a closed system from the dryer exit. All buildings in the post-dry area must have entryways and exits with self-closing doors and be screened. Any screening that is done in this area should be of the dual type-small mesh insect screen, covered and protected by the larger mesh "rat wire" (Fig. 2).

All ventilators and open eaves should be screened and open spaces in the walls where drags and conveyors enter the building should be tarred and pitched to prevent the entrance of insects and other vermin.

Walkways or driveways to and from the postdry areas should be paved and kept clean and dry. If practical, these passageways should be

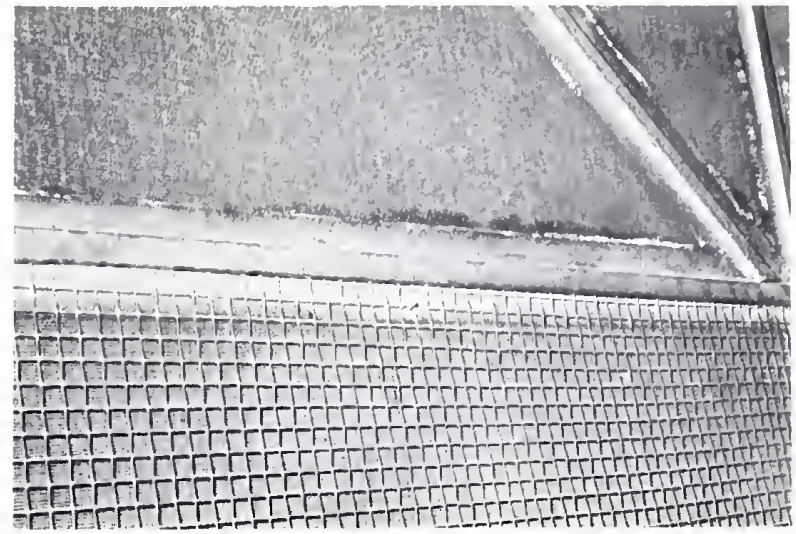

Figure 2. Dual type screening: insect screen covered with "rat wire."

covered. Any housing facilities for handling and storage; i.e., the post-dry areas, should have a concrete floor. Storage area walls, floors, and roofs should be leakproof to keep out moisture and to keep the processed product dry at all times. All conveyors in this area should be covered with metal covers and view plates should also be made of metal or transparent plastic (Fig. 3).

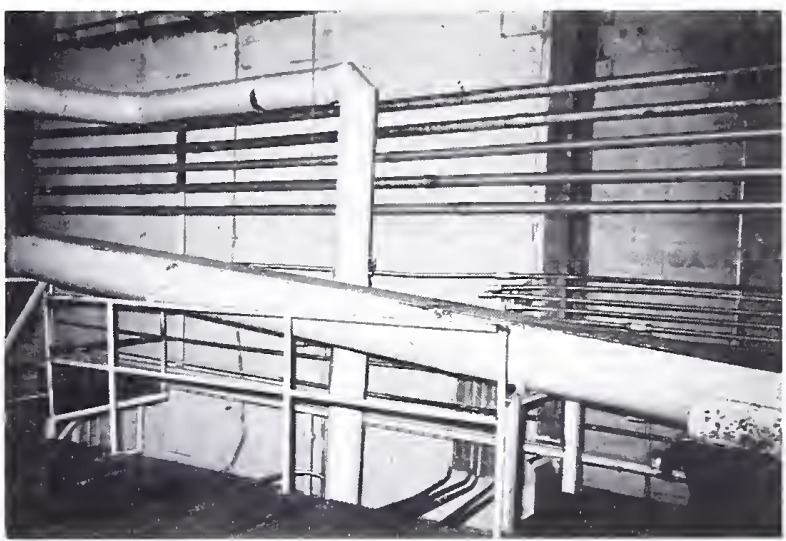

Figure 3. Properly covered conveyor.

A shallow pan containing a coconut fiber pad or other appropriate mat charged with an effective disinfectant should be placed by all entryways to the storage areas (Fig. 4). Phenolic, cresolic, or quaternary ammonic compounds are recommended as disinfectants. Hypochlorite types of disinfectants are not recommended since the bactericidal properties of these compounds are quickly lost and their use may represent a fire hazard. It is important that employees be trained in the proper use of 


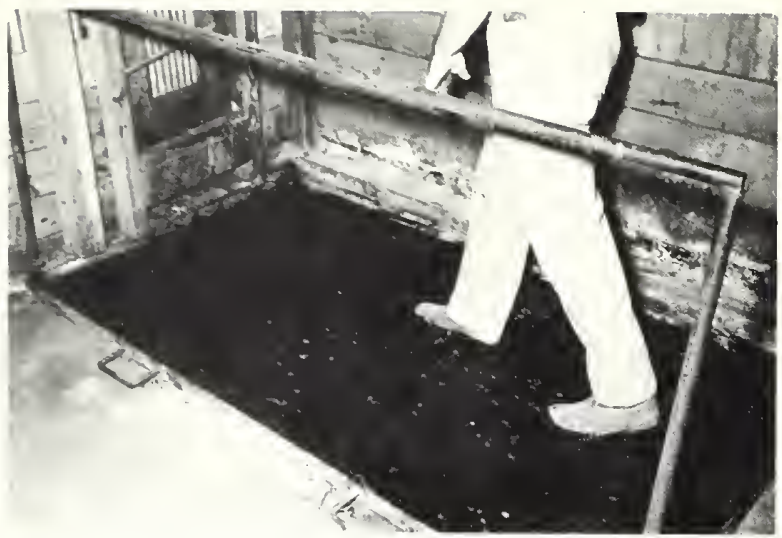

Figure 4 . Foot bath at entry of storage area.

the foot bath, and that the bath be changed on a scheduled basis.

The concept of the closed system in the post-dry area must extend to the loading facility. It is imperative for effective Salmonella control that the loading of carriers be carried out under conditions which will prevent contamination. Therefore, a screened loading facility is recommended.

\section{Cleaning and Disinfecting}

Raw material should be removed from drags, conveyors, and the unloading area as soon as possible after unloading is complete. Slime and scales should be washed from drags and conveyors with high-pressure hoses. For cleaning pre-dry processing equipment, we recommend a cleaning agent in hot water solution used with a detergent gun or high-pressure jets to loosen and remove grease and other materials sticking to the surface. Following an effective cleaning, the equipment may be sanitized or disinfected. A disinfectant having recognized germicidal properties should be used. (Spraying the equipment with a solution of sodium hypochlorite providing 500 parts per million of available chlorine is satisfactory for this purpose.) It must be remembered, however, that all surfaces must be free of grease and accumulated material prior to applying the disinfectant solution.

All truck beds, tanks, barrels, etc. used to transport raw material to the plant may be adequately cleaned and disinfected as described above.

During plant operations the post-dry cleaning procedures should generally be confined to dust control. During the curing process for dried fish scraps, small particles of the processed material collect on the floor in the vicinity of the scrap pile and should be cleaned up during intervals when the conveyors are not operating. After fish scrap and meal have been moved out and the shed is empty, it should be cleaned of residues of scrap and dust before receiving new materials. Dust that accumulates on sills, shelves, rafters, and equipment should be removed frequently; this is easily accom. plished by vacuuming (Fig. 5). All industrial vacuum cleaners discharging air in the warehouse should have their exhausts fitted with a filter to prevent airborne contamination. $\mathrm{Al}$ cyclone stacks in the post-dry area should be fitted with spring activated dampers which wil aid in dust control and prevent the entrance of pests and moisture during periods of inactivity.

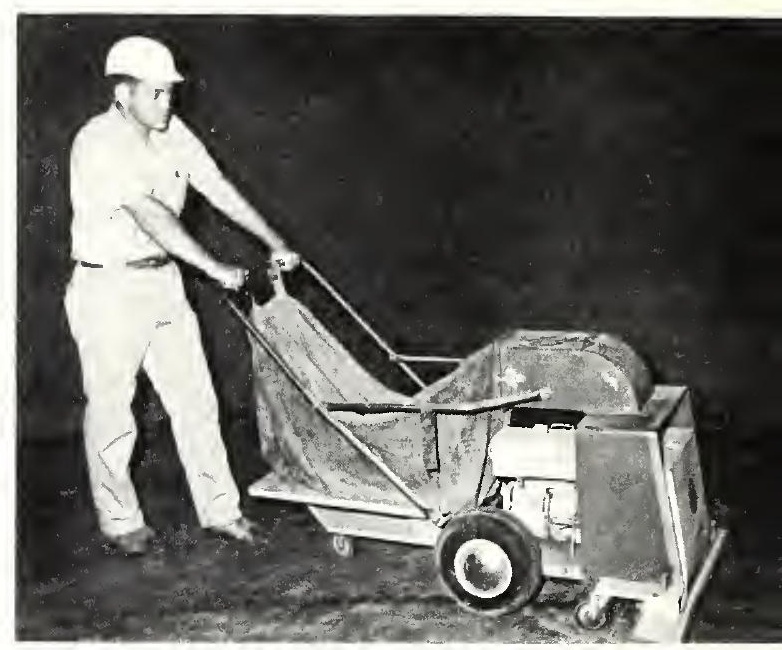

Figure 5. Use of vacuum machine aids in dust control

\section{Containers and Transportation}

Only new or sterile bags should be used for packaging processed material and the clean bag supplies should be stored in such a manner that they do not become contaminated.

The equipment used for transporting the processed material is a serious potential source for contaminating product during shipment. Generally, this equipment is not the property of the shipper, and thus there are acknowledged difficulties in maintaining it in clean condition. Even so, all equipment should be inspected before loading to see that it has been 
properly cleaned. If it is not clean, it snould receive proper cleaning. All carriers must be urged to cooperate in providing clean equipment.

Carriers may be fumigated with powdered formaldehyde or other effective bactericidal gas after a thorough cleaning, if necessary. Manufacturers' instructions must always be followed during the fumigation procedure.

\section{Sampling and Laboratory Examination}

Samples of the processed material at time of shipment should be periodically submitted for laboratory examination to determine the adequacy of the processing, handling, and storage methods (Fig. 6) in producing a Salmonella

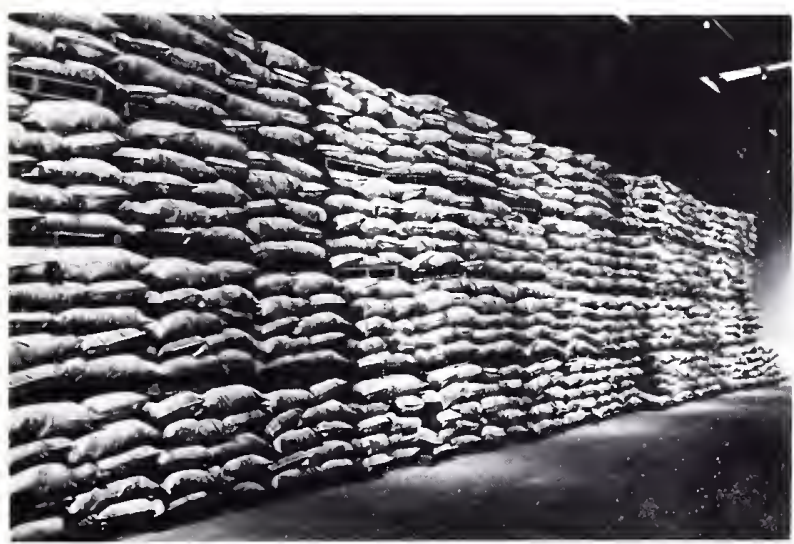

Figure 6. One method for proper storage of the finished product.

negative product. These samples may be taken by several methods. Each sample should contain 10 subsample units of at least 50 grams each. Samples may be collected while vehicles are being loaded by passing a sterilized scoop through the stream of material. In this case the approximate amount of time for loading the vehicle should be determined, this to be divided by 10 and 50 gram subsample units taken at proper time intervals. For example, should it take twenty minutes to load a vehicle, each 50 gram subsample unit would be taken at two minutes.

Another method for sampling bulk which has been loaded upon a vehicle is indicated in Figure 7. Probes 1 to 8 should be inserted at approximately $10-15^{\circ}$ angles from the vertical and approximately 10-12 inches from the edge

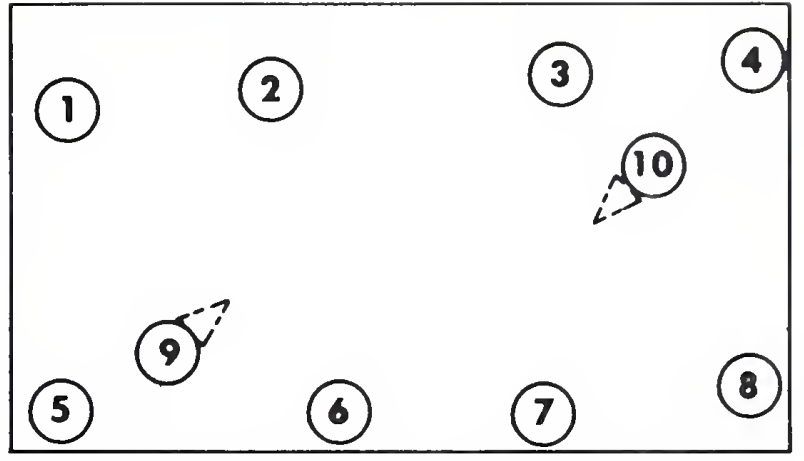

Figure 7. Diagram showing method of sampling bulk which has been loaded upon a vehicle.

of the vehicle bed. Probes 9 and 10 should be inserted at approximately $60-75^{\circ}$ angles from the vertical and as far out from the edge of the vehicle as can be reached without entering onto or walking on the material. (Sampling procedures courtesy of the USDA.)

All containers and instruments used in collecting the samples and subsample units must be kept sterile to avoid carryover from one sample or subsample unit to another.

Salmonella negative material may be defined as that processed material in which the presence of Salmonella is not detectable when sampled by procedures outlined in this guideline and subjected to a laboratory examination. The laboratory examinations should be done as outlined in USDA publication (ARS 91-68) "Recommended Procedure for the Isolation of Salmonella Organisms From Animal Feeds and Feed Ingredients."

Should the laboratory examination of the processed products reveal contamination, the sanitation procedures of the plant should be reexamined and corrective measures must be instituted.

\section{Personnel}

A sanitation officer should be appointed to ascertain that all aspects of these guidelines are carried out. All employees should be thoroughly instructed in plant sanitation guidelines and in the need for strict adherence to an accepted set of procedures (Fig. 8). Those personnel who work in the pre-dry areaincluding areas used for unloading, weighing, transporting, handling, or storing raw fishshould not work in the post-dry area and 


\section{T \& $\$$ II \\ H \& N D $\mathbf{N}$ \\ A I I I I 12 \\ II $S I N T$}

Figure 8. Instructional signs remind employees of proper sanitary procedures.

vice-versa without proper training. It is recommended that specially marked outer clothing, caps, and footwear be provided the employees that will readily identify their work area.

Adequate washing, showering, dressing, and toilet facilities must be provided for all employees.

\section{Management Responsibility}

There are certain basic and fundamental responsibilities the management of plants must accept for the implementation of these guidelines. First among these is the commitment to adequately fund a plant sanitation program. Unless such a program receives necessary funds, these guidelines cannot be effectively implemented. Secondly, there must be appointed at both the plant and corporate level one reliable individual who will be responsible for carrying out these guidelines. These individuals must interest all of the employees in proper sanitary practices. To do this, specific training sessions with films or other audio-visual aids may be used to explain the importance of good sanitary practices. All plants must be willing to undertake effective pest control programs. In many instances, it may be desirable to contract to outside individuals this function of the program. Finally, it is the responsibility of plant management to insure that good operational procedures are set forth in the day-today operation of a plant and that proper cleanup procedures are practiced. An excellent way to document proper operating and cleanup procedures is for a responsible individual to inspect the plant each day recording the inspection results on a score sheet (Fig. 9).

\section{SUMMARY}

1. Salmonellosis is a serious disease that may infect humans indirectly through animals which have eaten contaminated feeds.

2 . The organisms are reduced to nondetectable levels in fish meal when subjected to $190^{\circ} \mathrm{F}$ for 10 minutes.

3. Processed material should be negative for salmonellosis when exiting properly operated dryers. To make certain, however, the finished material from at least the first 45 minutes of production should be recycled back through the cookers.

4. Salmonella recontamination of the fish meal product can be controlled if the following preventive measures are taken:

a. Prevention of the indiscriminate transfer of men and equipment from the pre-dry area to the post-dry area.

b. Prevention of excessive moisture and dust accumulation in the post-dry area.

c. Proper pest and vermin control is maintained throughout the plant.

d. Proper cleaning in the pre- and post-dry areas of the plant is maintained.

e. Proper storage and shipment of the final product is carried out.

It must be recognized that currently Salmonella cannot be eradicated from fish meal. Therefore, a manufacturer can only hope to "minimize the risk." It is presently technically impossible to guarantee that a fish meal product is free of Salmonella microorganisms unless the product has been terminally treated. Sufficient data have been collected, however, to justify a statement that under good operating conditions, the probability of isolating salmonellae from the finished product is low. The purpose of these guidelines has been to delineate those "good operating conditions." 

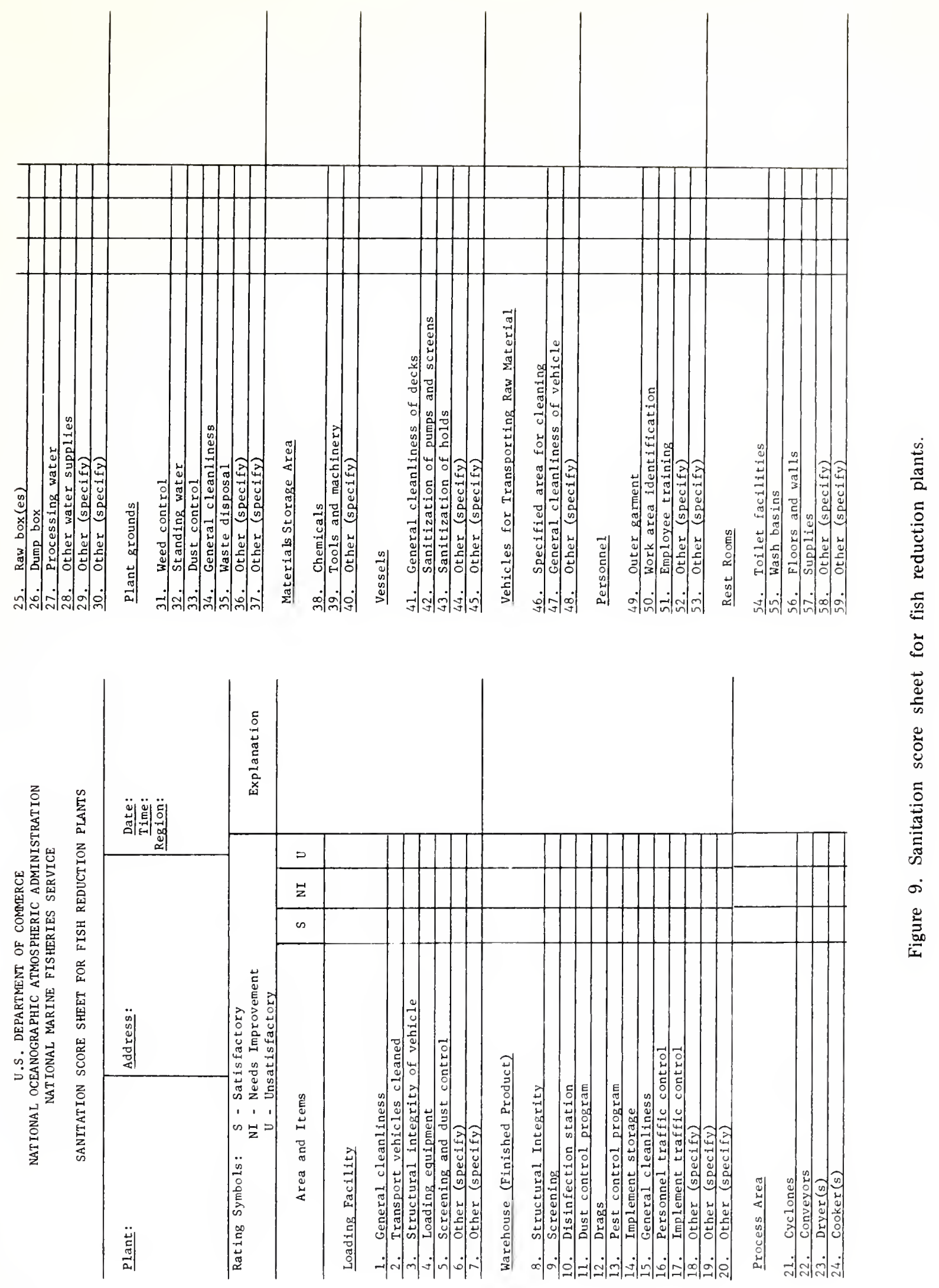

349. Use of abstracts and summaries as communication devices in technical articles. By F. Bruce Sanford. February 1971, iii +11 pp., 1 fig.

350. Research in fiscal year 1969 at the Bureau of Commercial Fisheries Biological Laboratory, Beaufort, N.C. By the Laboratory staff. November 1970 , ii +49 pp., 21 figs., 17 tables.

351. Bureau of Commercial Fisheries Exploratory Fishing and Gear Research Base, Pascagoula, Mississippi, July 1, 1967 to June 30, 1969. By Harvey R. Bullis, Jr., and John R. Thompson. November 1970 , iv +29 pp., 29 figs., 1 table.

352. Upstream passage of anadromous fish through navigation locks and use of the stream for spawning and nursery habitat, Cape Fear River, N.C., 1962-66. By Paul R. Nichols and Darrell E. Louder. October 1970 , iv +12 pp., 9 figs., 4 tables.

356. Floating laboratory for study of aquatic organisms and their environment. By George R. Snyder, Theodore H. Blahm, and Robert J. McConnell. May 1971, iii +16 pp., 11 figs.

361. Regional and other related aspects of shellfish consumption - some preliminary findings from the 1969 Consumer Panel Survey. By Morton M. Miller and Darrel A. Nash. June 1971, iv + 18 pp., 19 figs., 3 tables, 10 apps. 
UNITED STATES

DEPARTMENT OF COMMERCE

NATIONAL OCEANIC \& ATMOSPHERIC ADMINISTRATION NATIONAL MARINE FISHERIES SERVICE

SCIENTIFIC PUBLICATIONS STAFF

BLDG. 67. NAVAL SUPPORT ACTIVITY SEATILE, WASHINGTON 98115

OFFICIAL BUSINESS
PENN STATE UNIVERSITY LIBRARIES

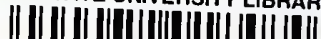

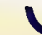

